\title{
Investments in Technological and Business Digitalization: Development of Accounting as a Factor of Economic Security for Business Entities in the Context of New Industrialization
}

\author{
Alexey Popov* \\ Ural State University of Economics, 620144 Ekaterinburg, Russia
}

\begin{abstract}
The article is devoted to the issues of reforming the investment costs accounting for the technological and managerial processes digitalization in the course of new industrialization. It outlines the factors for the accounting development, represents plans for the investment assets federal standards development, and evaluates their implementation. It formulates the key differences in the composition and recognition of costs that form the initial cost of digitalization objects. It features the issues of recognising software as part of intangible assets or expenses of the organization. The author analyses and criticise new norms of the introduced accounting standards that build up information about investment objects in the economic processes digitalization. The article also identifies the indicators of economic security formed on data on digitalization investments accounting and defines further directions for the development of accounting in terms of tangible and intangible investments.
\end{abstract}

\section{Introduction}

Modern situation in the entrepreneurial activity have outlined an actual trend in the development of the business entities economy, which at the moment is the digitalization of business. Initially, the definition of "digitalization" was formulated by an American computer scientist Nicholas Negroponte, who is currently working at the University of Massachusetts. Later this definition was studied by a number of Russian scientists, particularly O.A. Alekseenko..[1], Plotnikov V. A.[2], Avdeenko T. V, etc. Works by Sabbah K.[4], Blazer J.[5], Find M.[6] and others, devoted to this matter, also worth mentioning. According to V.G. Khalin, " digitalization in the narrow sense is understood as the transformation of information into digital form, which in most cases leads to lower costs, the emergence of new opportunities, etc. In a broad sense digitalization can be considered as a trend of effective global development only if the digital transformation of information meets the following requirements: it covers production, business, science, social sphere and ordinary people's lives; its results are used effectively; its results are

\footnotetext{
*Corresponding author: prepodpopov@yandex.ru
} 
available to users of transformed information; its results are used not only by specialists, but also by ordinary people; users of digital information have skills to work with it" [7].

At the same time, to ensure the implementation of the 2017-2030 strategy of the information space development in Russia, which approved by the President's Decree No.203 on May 09, 2017, business entities need to relocate their investment activities in the direction of digitalization of technological and business processes.

The Strategy of machine tool industry development for the period up to 2035, approved by the Government Decree N 2869-R of Overnumber 05, 2020 notes "a certain growth in domestic industry demand for high-tech, modern equipment, due to the rapid change in technological environment, and global change of the industrial paradigm towards integrated automation and production digitalization".

Hence, ensuring the sustainable development of domestic enterprises, strengthening their production potential and, accordingly, ensuring economic security is possible only if tactical and strategic business plans are adapted to the processes of digitalization, which require significant capital investments. At the same time, in a number of industries, there is a low level of investment and innovation activity, the reasons for which, according to the above Strategy, are:

"small amount of research and development work investment, due to the acute shortage of local financial resources for the implementation of breakthrough innovative projects;

lack of management that could encourage research and development investment

shortage of highly qualified personnel caused by the following factors:

weak generational continuity in research and development and production;

reduce in the number of graduates of specialized departments, stopping the influx of well-trained young specialists into science and production, including due to the uncompetitively low level of wages in comparison with the enterprises of the militaryindustrial complex;

outdated facilities and resources in the departments of most higher educational institutions;

lack of research and production centers integration;

low level of interaction between Russian consumers and products manufacturers at the development stage (in terms of demand formation and further commercialization);

lack of growth in the consumption of final machine tool products, that could provide an acceptable payback period for investment in research and development and capital investments".

Besides, to finance digitalization investment projects, to assess their reliability and calculate the payback and to determine their efficiency, business entities need complete and adequate information about the investments made, which should be based on accounting and financial statements. At the same time the current regulatory framework for accounting is extremely outdated, particularly, the Regulation on Accounting for Long-term Investments, which partially regulates how the information on capital investments is reflected in reporting papers, and was approved more than a quarter of a century ago, when the main trend in economic development was automation, not digitalization. Therefore, a number of Russian researchers, for example M.A. Sorokin[8],I.A. Varpaeva[9], V.I. Shevelev[10], mentioned the issues of investment accounting development in the conditions of new industrialization. The main direction of the accounting development in the Russian Federation is its integration with international financial reporting standards, which is covered in the works by R.N. Strelnikov[11], I. R. Sukharev[12], E. I. Stepanenko[13] and others. The experience of forming accounting systems abroad, disclosed in the works of Jackson S.B.[14], Ballantyne J.A.[15], Souder D.[16] and others, is also quite interesting. With all the completeness of the issues discussed in the above works, they need timely updating in connection with the Program for the Federal Accounting Standards 
Development, approved by the Russian Federation Ministry of Finance Order No. 83n of June 05, 2019, which approved the planned implementation of standards for accounting capital investments, fixed assets and intangible assets starting from 2021. However, due to a number of economic factors, the standards prepared by the accounting methodological center for fixed assets accounting (FSB 6/2020) and for the incomplete capital investments accounting (FSB 26/2020) were approved by the Russian Federation Ministry of Finance by Order No. 204n only on September 17, 2020 and will be applied to the accounting statements for 2022. For this reason, business entities are faced with the task of adapting accounting policies to the implementation of these standards, which will allow them to generate the necessary information about digitalization investments to solve strategic tasks and ensure economic security. Therefore, the purpose of this article is to highlight the key features of investments in digitalization accounting as a factor of economic security of business entities in the context of the new industrialization.

\section{Materials and Methods}

In course of this research, general scientific and special methods of studying accounting operations for investing in the digitalization of technological and business processes were used, such as description, generalization, comparison, extrapolation, analysis, etc. The author's proposed hypothesis states that investments in the economic processes digitalization are subject to correct and reliable recognition in accounting and financial statements, so that to assess the effectiveness of their application and strengthen the business entities economic security. The research is based on the works of local and foreign scientists, current legal acts, international standards, domestic standards drafts and other sources.

\section{Results and Discussion}

The objects of accounting of technological and managerial processes digitalization investments can be divided into two categories:

- necessary digitalization equipment - servers, local networks, processors, computer equipment and other objects that, according to accounting rules, are fixed assets;

- software digitalization tools, which, depending on the organization's rights, can be attributed to intangible assets (in case of exclusive rights), or to expenses if the organization acquires non-exclusive rights to use software tools under a license agreement

At the moment, the accounting of fixed assets is regulated by accounting regulation PBU 6/01, approved by he Russian Federation Ministry of Finance Order 26n of March 30, 2001, and in the accounting statements of 2022 it will be subject to the application of accounting federal standards FSB 6/2020. The above-mentioned objects - equipment necessary for digitalization, are assigned to this group of assets, since they meet the criteria of paragraph 4 of the Federal Tax Service on equipment:

- it is a tangible asset that has a material form;

- the purpose of this object is its use in the economic activity of a business entity;

- the equipment is meant to be used by a business entity for a long period exceeding 12 months, or during a long production cycle in case its duration is more than 12 months;

- it has the potential to generate economic benefits.

The accounting unit for fixed assets as objects of digitalization is an inventory object. According to FSB 6/2020," an inventory object in this case is an object of fixed assets with 
all devices and accessories, or an individual structurally autonomous object intended to perform certain independent functions, or a separate complex of set of structurally connected objects that represent a single whole and are intended to perform a certain work. A set of structurally connected objects is considered to be one or more objects of the same or different purposes, having common devices and accessories, common management, mounted on the same basis, as a result of which each object included in the complex can perform its functions only as part of the complex, and not independently. If one item of fixed assets has several parts, the cost and useful life of which differ significantly from the cost and useful life of the item as a whole, each such part is recognized as an independent inventory item."

When taking the software tools of digitalization into account, there are many issues to be debated.

As mentioned above, in accordance with the current PBU 14/2007, software digitalization tools can be classified as intangible assets, if they meet the criteria of paragraph 3 of the above standard, i.e. if these software tools meet the following requirements:

- they have the ability to generate economic benefits through their use in the economic activities of the organization;

- the business entity has the rights to receive these benefits, certified by the necessary documents confirming the existence of the asset itself, as well as the organization's rights to the results of intellectual activity or means of individualization;

- it is possible to identify an asset, including separating it from other property items;

- the software is aimed to provide a long period for production and management processes digitalization, which exceeds 12 months;

- the property is not planned to be resold in the short term;

- $\quad$ it is possible to give a reliable estimation of the initial cost;

- absence of a material form, except for the software carrier.

Meanwhile, according to The Federal accounting standard development program, the new "Intangible Assets" standard, as well as the "Fixed Assets" one, should go into effect from 2021. However, at the time of writing this article, the specified standard has not been approved by the Ministry of Finance, but there is a draft of it developed by the National Accounting Regulatory Authority Foundation "Accounting Methodological Center", submitted to the Accounting Standards Council.

According to this draft, the criteria for intangible assets recognition are narrowed to three elements (lack of a tangible form, use in the organization's activities and a long period of use), and it is additionally specified that intangible assets should include computer programs, as well as non-exclusive rights to the intellectual activity results.

Thus, starting from 2022, when, as expected by the accounting community, this draft standard goes into effect, if an organization acquires a software tool or a package with nonexclusive rights, it can be referred as intangible assets.

However, organizations don't acquire ownership of a number of software used in the process of the technological and business processes digitization, but acquire rights to use them under the license agreements, so these objects, according to the current PBU 14/07, shall be taken into account for the balance of the total amount of the contractual value for the entire period of the license agreement And periodic payments to copyright holders for the specified rights to use the software are subject to accounting as part of the organization's expenses. Meanwhile, if the user transfers a one-time lump-sum payment while obtaining the right to use this software, it is to be accounted as expenses of future periods with monthly withdrawals from current expenditures during the term of the contract. 
The Federal accounting standard "Intangible Assets" draft, which is planned to be put into effect, does not contain these provisions, so when making a decision on including acquired rights into intangible assets or expenses of an organization, it is necessary to adhere to the criteria for recognizing intangible assets prescribed in paragraph 4 of the Federal Accounting Standard draft.

In contrast to the current Russian Accounting Standard 14/07, "Intangible Assets" draft states that the intangible assets is not an inventory object similar to fixed assets, but a significant component of the object's value, with respect to which it is possible to determine the length for the period of future cash flows, or to establish the uncertainty of the specified period for the business entity..

When setting digitalization investment objects that are accounted for as part of fixed and intangible assets, their valuation is carried out at cost, while the formation of the initial cost is currently regulated directly by Russian Accounting Standard 6/01 and RAS 14/07. In 2022, when forming the initial cost of fixed assets, a fundamentally new standard of Federal accounting standard 26/2020 "Incomplete capital investments" will be applied to the procedure.

The general approach to setting the initial cost for digitalization investment objects according to the current and planned accounting standards has retained its tradition, that is, their initial cost is formed as the sum of costs incurred during the acquisition or creation of objects. At the same time, when dealing with intangible assets, the principal point is that when creating an innovative product for which a scientific research is necessary, the expenses incurred at the research stage are not capitalized, but are recognized in the statement of financial results. Since at the time of writing this article, the final version of the planned standard for accounting intangible assets has not been approved, the main focus will be on an unambiguous procedure of evaluating material investments in digitalization.

The analysis of the fixed assets initial cost components according to the current and planned standards is presented in table 1.

Table 1. Components forming the investment object initial cost

\begin{tabular}{|c|c|c|c|}
\hline $\begin{array}{l}\text { Items that form the initial } \\
\text { cost according to Russian } \\
\text { Accounting Standard } 6 / 01\end{array}$ & $\begin{array}{l}\text { Cost items saved in the } \\
\text { Federal accounting } \\
\text { standard 26/2020 }\end{array}$ & $\begin{array}{c}\text { Additional cost } \\
\text { items listed in } \\
\text { Federal } \\
\text { accounting } \\
\text { standard 26/2020 } \\
\end{array}$ & $\begin{array}{l}\text { Cost items excluded } \\
\text { from the standard } \\
\text { and combined by } \\
\text { the "other costs" } \\
\text { definition }\end{array}$ \\
\hline $\begin{array}{l}\text { - money paid to the supplier } \\
\text { (seller) according to the } \\
\text { contract, as well as money } \\
\text { paid for the object delivery } \\
\text { and bringing it into a } \\
\text { condition suitable for use; } \\
\text { - money paid to } \\
\text { organizations for a work } \\
\text { done under the construction } \\
\text { contract and other contracts; } \\
\text { - money paid to } \\
\text { organizations for } \\
\text { information and consulting } \\
\text { services related to the } \\
\text { acquisition of fixed assets; } \\
\text { - customs duties and } \\
\text { charges; nans } \\
\text { - non-refundable taxes } \\
\text { and/or state duty paid for } \\
\text { acquiring an item of } \\
\text { property, plant and } \\
\text { equipment; faid to the }\end{array}$ & $\begin{array}{l}\text { - amounts paid and (or) } \\
\text { payable by the organization } \\
\text { to the supplier (seller, } \\
\text { contractor) when making } \\
\text { capital investments; } \\
\text { - the value of the } \\
\text { organization's assets written } \\
\text { off because of the use of } \\
\text { these assets in the } \\
\text { implementation of capital } \\
\text { investments; } \\
\text { - devaluation of assets used in } \\
\text { making capital investments; } \\
\text { - costs of maintaining the } \\
\text { operability or serviceability } \\
\text { of assets used for capital } \\
\text { investments, and of } \\
\text { maintaining these assets; } \\
\text { - wages and any other forms } \\
\text { of payment to the company } \\
\text { employees whose work is } \\
\text { used for capital investments, } \\
\text { as well as all social payments }\end{array}$ & $\begin{array}{l}\text { - interest related to } \\
\text { the capital } \\
\text { investments that are } \\
\text { to be included into } \\
\text { the investment } \\
\text { asset value; } \\
\text { - the amount of the } \\
\text { estimated liability } \\
\text { incurred during the } \\
\text { implementation of } \\
\text { capital investments, } \\
\text { including for the } \\
\text { future dismantling, } \\
\text { disposal of property } \\
\text { and revival of the } \\
\text { environment, as } \\
\text { well as the use of } \\
\text { labour of the } \\
\text { organization } \\
\text { employees; }\end{array}$ & $\begin{array}{l}\text { - money paid to } \\
\text { organizations for } \\
\text { information and } \\
\text { consulting services } \\
\text { related to the fixed } \\
\text { assets acquisition; } \\
\text { - customs duties and } \\
\text { charges; } \\
\text { - non-refundable } \\
\text { taxes and/or state } \\
\text { duty paid for } \\
\text { acquiring an item of } \\
\text { property, plant and } \\
\text { equipment; } \\
\text { - fees paid to the } \\
\text { intermediary } \\
\text { organization through } \\
\text { which the article of } \\
\text { fixed assets was } \\
\text { purchased. }\end{array}$ \\
\hline
\end{tabular}


Table 1. Continued

\begin{tabular}{|c|c|c|}
\hline $\begin{array}{l}\text { intermediary organization } \\
\text { through which the article of } \\
\text { fixed assets was purchased; } \\
\text { - other costs directly related } \\
\text { to the acquisition, } \\
\text { construction and } \\
\text { manufacture of an item of } \\
\text { property, plant and } \\
\text { equipment. }\end{array}$ & $\begin{array}{l}\text { related to these salaries } \\
\text { (pension, health insurance, } \\
\text { etc.); } \\
\text { - other costs recognised as } \\
\text { part of capital investments } \\
\text { cost. }\end{array}$ & $\begin{array}{l}\text { - costs for } \\
\text { maintaining the } \\
\text { working efficiency } \\
\text { or good condition } \\
\text { of capital } \\
\text { investments assets, } \\
\text { as well as for } \\
\text { mending these } \\
\text { assets. }^{*}\end{array}$ \\
\hline
\end{tabular}

It should be noted that while Russian Accounting Standard 6/01 does not consider the issue of fixed assets independent building by an organization separately, when forming their initial cost the extrapolated norm of RAS 5/01 is use, According to it "the actual cost of the objects stated is determined by the actual costs for the production of the stocks, and their accounting and pricing is carried out by the organization following the procedure established for determining the cost of the corresponding types of products". If we consider digitalization equipment as scientific and technical items, then to calculating the initial cost, it is allowed to use Standard Methodological Recommendations for Planning, Accounting and Calculating the Cost of Scientific and Technical products, that were approved by the Ministry of Science of the Russian Federation of order by June 15, 1994. No OP-22-2-46, if it does not contradict the current accounting standards, particularly RAS 5 and 6 . This document contains a reference to the cost structure, which includes the costs for assets depreciation and use, employee wages, including mandatory insurance payments, and other costs specified in Federal accounting standard 26.

The fundamental difference between the Federal accounting standard and the current RAS is the issue he initial cost adjustment to the amount of discounts provided at the time of purchase, if this discount was provided after the sale, since previously the initial cost of fixed assets accepted for accounting was not subject to change.

Another important difference is the assessment of the initial cost for fixed assets on deferred payment terms exceeding 12 months, or a shorter period established by the organization. In this case, the assessment should be based on the amount of money to be transferred in case of immediate payment, and the difference between the nominal debt under the contract and the recognized value should be accounted as prescribed by the order of accounting debt costs (interests are accounted in accordance with RAS 15/08). However, in this case, it is also necessary to take the time of re-qualification of the capital investments in fixed assets into account. If the process of acquisition, construction and manufacture of fixed assets continues during the deferred/installment period and the object being acquired or created is recognized as an investment asset, then the interest is liable for capitalization and attributed to the initial cost. And if the process of acquisition, construction or manufacture is completed and the object of fixed assets capital investment is re-qualified, then the interest for the installment period is subject to attribution to other expenses to 91-2 account. A fundamentally new norm is the introduction of fair value as a mean of investment assets assessment in the case of uncompensated receipts, as well as if the objects were received under contracts providing the fulfilment of obligations via non-monetary means (particularly under barter agreements).

Furthermore, fair value is determined by the norms of International Financial Reporting Standards (IFRS) 13, according to which it is understood as "the price that would be received when selling an asset or paid when transferring a liability in current market conditions in an organized market and between market participants at the measurement date". First of all fair value measurement takes into account the assets quoted prices, that 
are given the highest priority. The second is observable data, which are sometimes adjusted to reflect s[ecific differences, and the third is unobservable data, the use of which should be minimized. Market, revenue and cost methods can be used to estimate fair value. Meanwhile transaction costs do not adjust the fair value, but are taken into account when determining the most profitable market, and transport costs are adjusted if they need to be incurred to deliver the asset from its current location to the most profitable market.

An important point in determining the initial cost of material investments in the technological and business processes digitalization is when, in case of equipment adjustment or testing, the organization receives spare parts or other material values that can be realized or used in economic activities. The estimated value of these assets should reduce the amount of capital investment, while the specified estimated value is based on the fair value or net sale value of analogue objects.

Materials and supplies inventories that the organization did not use in the capital investments implementation are also taken into account by the same order. Besides, an accounting entry should be made in the debit account of the specified material property and in the loan accounts for non-current assets investments.

The Federal accounting standard 26/2020 makes a special emphasis on costs that are not included in the capital investments cost/ These include usual payments, especially "costs incurred before making a decision on the acquisition, creation or improvement of the investment assets object, costs incurred because of natural disasters, fires, accidents and other emergencies, depreciation of assets that were used in the capital investments, management costs, advertising costs, training of the personnel engaged in the digitalization process, etc." 2

But principal attention should be paid to the costs that are not included in the initial cost, and that rose from poorly organized capital investments process (including excess consumption of raw materials, materials, energy, labour, losses from downtime, defective articles, labour violations and technological discipline). But while it is possible to agree with the non-inclusion of downtime, defective articles and labour violations in the initial cost, mentioned in paragraph 16 of Federal accounting standard 26/2020, this item is not tenable when speaking of excess consumption of raw materials, labour and energy, since the business digitalization implementation in industrial enterprises is an ambitious innovative project, and to figure out the standards for its implementation at the design stage is not always possible due to the emerging features of the technological process and the organization of production. Therefore, in our opinion, this paragraph needs to be adjusted accordingly before this standard comes into force.

Also, when getting the capital investments initial cost, they should be tested on impairment and, if there are signs of it, the impairment reduces the carrying amount of the objects, which, in its turn, will adjust the cost of the digitalization equipment in the future..

\section{Conclusions}

To conclude the above, when implementing projects for technological and business processes digitalization in the situation of new industrialization, the considered principles of investment costs formation will allow business entities to evaluate investment projects, calculate their effectiveness for strengthening economic security. The main accounting legislation innovations for figuring out the value of material investment objects in digitalization process are as follows::

- expansion of the list of costs included in the initial cost, particularly for the amount of estimated liabilities;

- adjusting the objects cost to the amount of discounts, bonuses, rewards and benefits, regardless of how they were providied; 
- the need to apply the discount method when calculating the initial cost of objects purchased on a long-term deferred/installment basis;

- application of fair value in case of uncompensated receipts of objects and in case of receipt under barter agreements;

- investments cost reduction for the cost of spare or/and unused parts during the installation and adjustment of facilities.

Besides, when making investments by software acquisition, its recognition as part of intangible assets is justified if the organization has non-exclusive rights to the object.

The information on business entities investment activity aimed at digitalization, that was received while their recording, will allow to evaluate indicators of economic security at the regional and federal levels, especially according to the indicators approved by the Ministry of Economic Development Order of February 12, 2020 No. 66 " On approval of methodological recommendations for statistical assessment of the Russian economy (as a whole and of its Branches) technological development. Some of these indicators include:

- $\quad$ "Share of organizations using cloud services in the total number of organizations;

- Share of organizations with Internet access with a speed of at least $2 \mathrm{Mbit} / \mathrm{s}$ in the total number of organizations;

- Share of organizations using CRM systems, ERP systems, and SCM systems in the total number of organizations;

- Share of organizations placing orders for goods, works, services on the Internet, in the total number of organizations surveyed".

Further areas of scientific research on this problem include the adaptation of the ready to adopt "Intangible Assets" standard for the business entities, and the current Accounting Chart of Bookkeeping, as well as the development of recommendations for the application of the Federal accounting standard 6/2020 and 26/2020 om issues not regulated by these standards.

\section{References}

1. O.A. Alekseenko, I.V. Ilyin, Information Society, 2, 25 (2018)

2. V. A. Plotnikov, Bulletin of the St. Petersburg State University of Economics, 4(112) (2018)

3. T. V. Avdeenko, A. A. Aletdinova, Scientific and technical bulletins of St. Petersburg State Polytechnic University. Economic sciences, 10 (2017)

4. K. Sabbagh, Digitization for economic growth and job creation: Regional and industry perspective, The global information technology report, 35 (2013)

5. J. Bleicher, H. Stanley, J. of Business Management, 12 (2016)

6. M. Maiti, P. Kayal, Asian Economic and Financial Review, 7(6), 541 (2017)

7. V. G. Khalin, G. V. Chernova, Management consulting, 10(118) (2018)

8. M.A. Sorokin, Problems of accounting and finance, 2 (2011)

9. I.A. Varpaeva, Development of accounting for the costs of investment activities of the organization (2012)

10. V.I. Shevelev, S.N. Nikulina, I.N. Sheveleva, Problems and prospects of development of engineering and construction science and education, 89 (2019)

11. R.N. Strelnikov, Theoretical and practical aspects of economy and intellectual power, 2 (2), 178 (2015)

12. I.R. Sukharev, O.A. Sukhareva, International accounting, 8 (2009) 
13. E.I. Stepanenko, S.A. Chevrychkin, Information support for effective management of economic entities, 250 (2016)

14. S. B. Jackson, X. K. Liu, M. Cecchini, Journal of Accounting and Economics, 48(1), 54 (2009)

15. J. A. Ballantine, S. Stray, Logistics information management (1999)

16. D. Souder, P. Bromiley, Strategic Management Journal, 33(5), 550 (2012) 